\title{
長時間の立体映像視聴が体平衡系および自律神経系に及ぼす影響
}

\author{
木下 史也 $*^{1}$, 森 柚樹 $*^{2}$, 杉浦 明弘*3, 山川 達也 *1, \\ 松浦 康之 $*^{4}$, 高田 宗樹 $*^{2}$, 宮尾＼cjkstart克 $*^{1}$ \\ *1 名古屋大学大学院情報科学研究科情報システム学専攻 \\ *2 福井大学大学院工学研究科知能システム工学専攻 \\ *3岐阜医療科学大学保健学部放射線技術科学科 \\ *4 名古屋市立大学大学院システム自然科学研究科理学情報専攻
}

\section{Effect of Viewing a Long Stereoscopic Film on Equilibrium Function and Autonomic Nervous System}

\author{
Fumiya KINOSHITA*1, Yuki MORI*2, Akihiro SUGIURA*3, Tatsuya YAMAKAWA*1, \\ Yasuyuki MATSUURA*4 ${ }^{4}$ Hiroki TAKADA*² and Masaru MIYAO*11 \\ *lDepartment of Information Engineering, Graduate School of Information Science, Nagoya University \\ *2Department of Human and Artificial Intelligent Systems, Graduate School of Engineering, University of Fukui \\ ${ }^{*}$ Department of Radiology, Gifu University of Medical Science \\ ${ }^{*}$ Department of Information and Basic Science, Graduate School of Natural Sciences, Nagoya City University
}

\begin{abstract}
Objectives: Owing to the recent rapid advancements in image processing and threedimensional (3-D) technologies, stereoscopic images can now be viewed on television as well as in theaters and on gaming consoles among others. However, with these advancements, there have also been reports on motion sickness and asthenopia induced by viewing stereoscopic films. Human equilibrium function deteriorates when viewing stereoscopic films, which may lead to motion sickness; however, the exact cause of such motion sickness remains unknown. Therefore, as part of hygiene research that contributes to society, it is important to consider the safety of viewing virtual 3D contents.

Methods: In this study, we investigated the effects of viewing 2-D/3-D video clips on the human body by stabilometry, electrogastrography (EGG), and subjective assessments. Seven subjects aged 22 to 24 viewed 2-D/3-D video clips for $60 \mathrm{~min}$.

Results: A comparison of time series data obtained at rest shows a significant change in the EGG patterns 20 min after the start of viewing the video clips. Furthermore, sway values while viewing the 3-D video clips were considerably higher than those while viewing the 2-D video clips $60 \mathrm{~min}$ after the start of viewing.

Conclusions: These findings show that the autonomic nervous system is affected first by long-term viewing of stereoscopic films, and the equilibrium function deteriorates gradually over the course of the exposure.
\end{abstract}

Key words: stereoscopic film（立体視）, motion sickness（動摇病）, stabilometry（重心動摇検査）, electrogastrography（胃電図検査）， Simulator Sickness Questionnaire（SSQ）

受付 2015 年 6 月 26 日, 受理 2015 年 10 月 15 日

Reprint requests to: Masaru MIYAO

Department of Information Engineering, Graduate School of Information Science, Nagoya University, Furo-cho, Chikusa-ku, Nagoya, Aichi 464-8603, Japan

TEL: +81(52)789-4363

E-mail: mmiyao@is.nagoya-u.ac.jp

\section{1.はじめに}


(1)，ホログラフィ方式 (2) など多くの方式が提案され ている。しかし, 立体映像はその視聴条件により, 不快 感や眩量感など眼疲労の症状を引き起こすことが報告さ れている（3）。立体映像が生体に及ぼす影響についての 知見は十分でなく, 実証研究を蓄積させることは, 安全 な立体映像の視聴を検討する上で不可欠である (4)。

映像酔いの発生機序については，動摇病のそれ之同様 に感覚不一致説が一般的である (5)。体平衡系は視覚系・ 前庭系・体性感覚系の情報を入力としているが，これら の情報の組み合わせが，それまでの経験によって確立し た感覚系の情報の組み合わせと一致しない時に, 空間識 が不安定となり頭痛・嘔吐などの動摇病症状が生ずると いら仮説である。体平衡系で最も参照されると考えられ る前庭系からの生体信号は, 脳幹に位置する前庭神経核 にも投射される。平衡感覚信号はこの前庭神経核を介し て, 脊髄運動ニューロンや眼運動ニューロン, 前庭小脳, 大脳皮質抽よび脳幹自律中枢といった上位の中枢へ中継 される。特に, 後者の前庭一自律神経系により, 前庭刺 激が延髄の嘔吐中枢に達することを意味しており，乗り 物酔いも前庭自律神経反射によってもたらされる。また, 前庭系と自律神経系とは, 解剖学的にも電気生理学的に も密接な関係があることが知られている $(6,7)$ 。これは 酔いによる不快症状との関係を強く示唆するものであ り, 酔いを体平衡系の出力である重心動摇にて定量的に 評価する根拠になり得る。

重心動摇を定量的に評価する一つの方法として, 重心 動摇検査が存在する。重心動摇検査は体平衡系が安定し たとみなせる時点から動摇図の記録を開始し，60秒間を 基準とする検査であり, 体平衡系の安定性評価や中枢の 疾患による平衡機能障害の診断など平衡機能の総合的把 握に有用である。重心動摇の診断的価值を高める目的で 動摇図の解析指標が提案されており, 総軌跡長, 単位面積 軌跡長などが存在する $(8)$ 。一般的に, 重心動摇検査は立 位により計測が行われるが,アルコール摂取が重心動摇に 及ぼす影響に関する先行研究では, 立位で示された動摇量 の増加が座位でもみられて扣り, 酔いを座位における重 心動摇を利用して評価することが検討されている（9）。

一方，自律神経活動に関する生理的計測手法として 胃腸の電気活動を体表面から記録する経皮的胃電図 (Electrogastrogram, EGG) が存在する (10)。胃電図は, 胃腸運動を制御する電気活動を無拘束に測定できるひと つの方法であり, 他の消化管機能検査法に比べて非侵襲 で測定することが可能であるため, 長時間測定が可能で ある。そのため食事や睡眠時の生体状態評価, 疾病診断 や病態評価への応用, 消化管運動に関する新しい知見を 得ることが期待される。胃の電気活動を司るペースメー カーは胃体上部 $1 / 3$ 大彎側に存在し，ここからヒトでは 1 分間に約 3 回の波 (3 cycle per minute, cpm) が幽門部に 向かって電気活動を伝播している。このペースメーカー は迷走神経活動の支配を受けているが，自発的に周期的 電気活動を起こしている。これはCajalの間質細胞, また
は Cajalの介在細胞 (Interstitial cells of Cajal, ICCs) と呼ば れる細胞群のネットワークによるものである (11-13)。

本論文では 60 分間の長時間立体映像視聴が体平衡系 の出力である重心動摇検査抢よび消化管運動の客観的指 標である胃電図に及ぼす影響について検討した。また, Simulator Sickness Questionnaire（SSQ）といった主観評 価を交えることで，長時間の立体映像視聴が生体に及ぼ す影響について多角的評価を行った。

\section{2. 方法}

\section{1 実験方法}

被験者は耳・神経系疾患既往歷のない若年男性 7 名 (平 均土標準偏差 : $22.3 \pm 0.8$ 歳) を対象に行った。被験者 には事前に実験の説明十分に行い, 了承を得た。な拈, 本実験は名古屋大学情報科学研究科の倫理審査委員会の 承認を得ている。

本実験では，背もたれのない高さ $60 \mathrm{~cm}$ の台の上に厚 さ $1 \mathrm{~cm}$ の板を置き, その上に重心動摇計を地面と水平 に設置した。被験者には重心動摇計上で背筋を伸ばした 座位をとらせ，両足非接地にて拳を軽く握り膝上に置く よら指示を行った。実験は, 20 分間の安静の後, 60 分 間の映像視聴を行った。胃電図検査は 20 分間の安静抒 よび映像視聴開始後 60 分間を連続して記録した。重心 動摇検査は 20 分間の安静の後, 映像視聴前の記録を行 い, 映像視聴開始後 20 分ごとに計 3 回記録した。重心 動摇検査は開眼検查, 閉眼検査を実地し, 開眼検査では 映像を視聴したまま測定を行い，測定時間はそれぞれ 1 分とした。本実験では重心動摇計として Wii Balance Board（Nintendo）を使用した。このシステムの測定点 の座標は $\mathrm{cm}$ 単位で, 時間分解能は $0.01 \mathrm{sec}$ である。胃 電図検査は単極誘導で測定を行い, 生体アンプ MT11 （NECメディカル）にて得られた胃電図のアナログデー タを増幅し，データレコーダ PC216Ax（ソニー・プレ シジョンテクノロジー）に記録した。胃電図の測定方法 はいくつかの手法が提案されて扣り, 電極の個数掞よび その貼付位置にも数種類の方法がある。しかし, ぞの手 法も電極の貼付位置として胃のペースメーカーに最も近 い部位は必ず測定している。そこで, 本論文でも胃のペー スメーカーに最も近い部位に心電図用ディスポーザブル 電極ビトロード Bs（日本光電）を貼付した（Fig. 1)。 な抢，電極の貼付は日本光電製スキンピュアにより皮膚 抵抗を十分に低下させた後に行った。

映像は被験者から $2 \mathrm{~m}$ の距離に目の高さが中心になる よう設置された 40 インチディスプレイ KDL 40HX80R (SONY) 上に市販の両眼立体視映像およびその片眼視 用の 2D 映像を提示した。映像は円偏光方式を用いた表 示方式を採用し, 映像の提示順はランダムとした。な拉, 実験は各被験者で別日に行った。各重心動摇検査の測定 後, 被験者には SSQ 用紙に記入させ，映像酔いに関する 主観的評価を行った。日内変動の影響を考慮し，全被験 


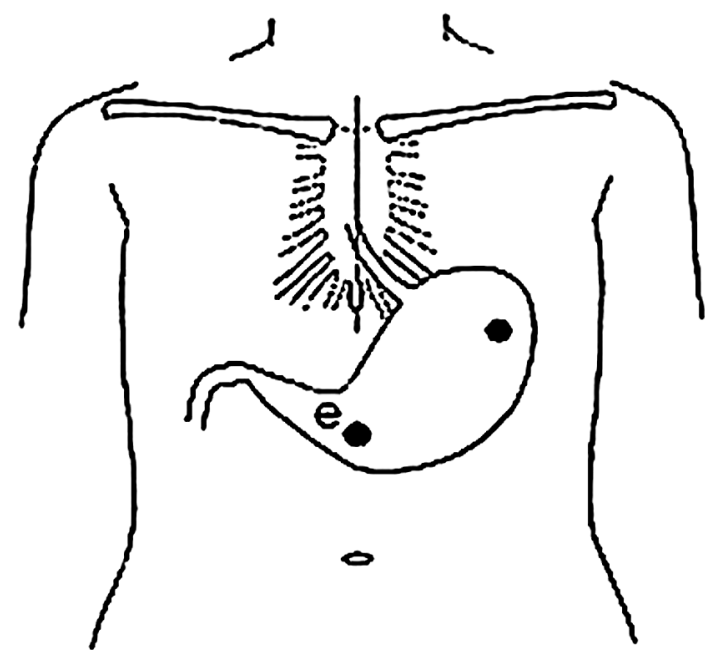

Fig. 1 Electrode position

者平日の午後 2 時一午後 3 時の間に測定を開始し, 食事 は測定開始 2 時間前までに摂取するように指示を行った。

\section{2 重心動摇検査による検査事項}

開眼検査拉よび閉眼検査で各サンプリング時間に括け る $\mathrm{x}-\mathrm{y}$ 座標を記録し, 各指標の算出を行った。得られた データは, 開眼検查掞よび閉眼検查ごとに $\mathrm{x}$ 方向 (右方向 を正), y 方向（前方方向を正）とする重心位置の時系列 に変換し, 外周面積, 総軌跡長, 単位面積軌跡長, 疎密度 について評価を行った。外周面積, 総軌跡長, 単位面積 軌跡長は既往の研究に打いて用いられている動摇図の解 析指標であり, 本論文でも日本めまい平衡医学会の定義 式に基づいた。また，疎密度とは高田らによって提案さ れた平面上に散布した複数点の密度を示す指標であり, この密度が立位姿勢の安定性に関与すると考兄らてい る(14)。各指標の定義については以下の通りである。

- 外周面積 : $\mathrm{x}-\mathrm{y}$ 座標における動摇の外周の囲む線で包 まれる面積であり, 值の増加は動摇の不安定性を示す。

- 総軌跡長 : 計測時間内の重心点の移動した総延長距離 であり，值の増加は動摇の不安定性を示す。

・単位面積軌跡長 : 総軌跡長を外周面積で除した值のこ とであり，值の減少は動摇の不安定性を示す。

・疎密度 : 動摇図を正方形で分割し, 各分割で足圧中心 が通過した回数を求める。動摇が少なければ，つまり 局所的に密度が高い場所に存在するほど值は 1 に近づ く。逆に，動摇が疎らになれば值は大きくなる。

\section{3 胃電図検査による検査事項}

本論文では，記録した胃電図を $1 \mathrm{kHz}$ にて $\mathrm{A} / \mathrm{D}$ 変換 を行い, 時系列データを得た。混入筋電図や周りの電子 機器からの電気的雑音の除去のために, 得られたデータ に高域遮断周波数 $0.15 \mathrm{~Hz}$ のローパスフィルタを適用し, 高周波成分を除いたものに，さらに $1 \mathrm{~Hz}$ で再サンプリ ングを行い，ノイズ除去を行った。胃電図データは，映
像視聴開始後 20 分ごとに分割し，抽出した時系列につ いてそれぞれ解析した。

胃電図の解析には周波数解析と Wayland アルゴリズム によって推定される並進䛊差なる統計量を用いた（15, 16)。胃電図の正常周期は2.4-3.7 cpm であることから (17)，この周波数帯域に着目し，分割された胃電図デー タに高速フーリエ変換を行いピーク周波数打よび正常周 期でのパワースペクトル密度を算出した。Waylandアル ゴリズムによって推定される並進誤差 $\left(E_{\text {trans }}\right)$ は位相空 間に埋め込まれたアトラクタの軌道の滑らかさを定量的 に評価する指標である。埋め込久空間で再構成されたア トラクタの軌道が滑らかであれば，時系列に決定論性が あるといえる。並進誤差は正の值をとり，0に近ければ 時系列を生成する数理モデルが決定論的，大きければ確 率論的とみなすことができる。特に，対象がブラウン運 動であるときは並進誤差の值は 1 と推定される。

\section{4 検討事項}

重心動摇検査により得られた映像視聴開始前および開 始後の各動摇図について, 開眼検査, 閉眼検査における 外周面積, 総軌跡長, 単位面積軌跡長および踈密度を算 出した。各指標において視聴映像, 視聴時間による差異 を因子とする二元配置分散分析を行らとともに，各水準 に扣ける母平均に差がないことを帰無仮説とする対応の あるWilcoxonの符号付き順位和検定を用いて多重比較 を行った。胃電図データは, 分割した各時系列において ピーク周波数， $2.4-3.7 \mathrm{cpm}$ でのパワースペクトル密度 （以降，PSD と表記）扎よび並進䛊差を算出した。胃電 図データでの各指標は映像視聴開始前と開始後 20 分ご とにWilcoxonの符号付き順位和検定にて比較を行った。 本論文では有意水準を 0.05 とした。

\section{3. 結果}

映像視聴開始前および開始後 60 分時で記録された開 眼検査での動摇図の典型例を Fig. 2 に示す（同一被験 者)。映像視聴開始前における開眼検査での動摇図分布 の広がり（最大值一最小值）の平均土標準偏差は $\mathrm{x}$ 方向 では $0.32 \pm 0.11 \mathrm{~cm}, \mathrm{y}$ 方向で $0.48 \pm 0.26 \mathrm{~cm}$ となり, 2D 映像視聴開始後 60 分時では $\mathrm{x}$ 方向で $0.28 \pm 0.03 \mathrm{~cm}, \mathrm{y}$ 方向で $0.32 \pm 0.08 \mathrm{~cm}$ となった。立体映像視聴開始後 60 分時での動摇図分布の広がりはx 方向で $0.43 \pm 0.30 \mathrm{~cm}$, $\mathrm{y}$ 方向で $0.65 \pm 0.60 \mathrm{~cm}$ となった。動摇図分布の広がりは, 映像視聴開始前に比べ開始後 60 分時において $2 \mathrm{D}$ 映像 視聴時では $\mathrm{x}$ 方向, $\mathrm{y}$ 方向ともに小さくなり，立体映像 視聴時では $\mathrm{x}$ 方向，y方向ともに大きくなった。

映像視聴開始前扣よび開始後 60 分時で記録された胃 電図波形の典型例を Fig. 3 飞示す（同一被験者）。胃電 図波形から，いずれの胃電図にも正常な周期変動（2.4$3.7 \mathrm{cpm})$ がみられ，腸管の電気活動由来の成分が重盢 されている。 

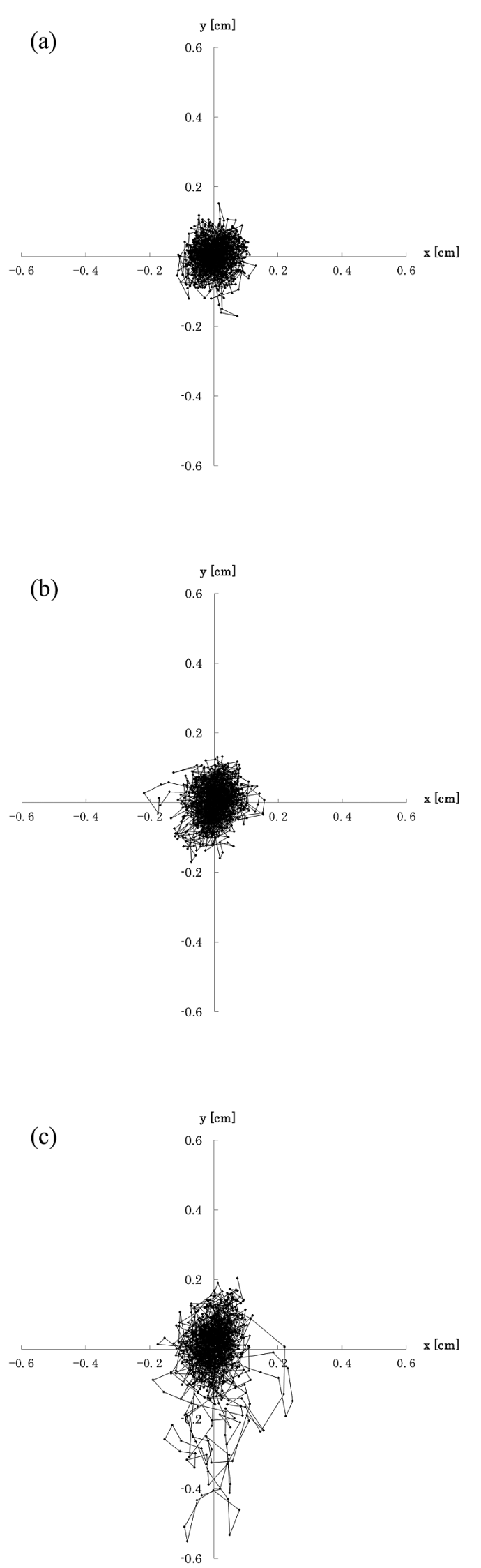

Fig. 2 Typical stabilograms. a, before viewing a video clip with opened eyes; b, viewing 2D video clip with opened eyes; c, viewing $3 \mathrm{D}$ video clip with opened eyes.
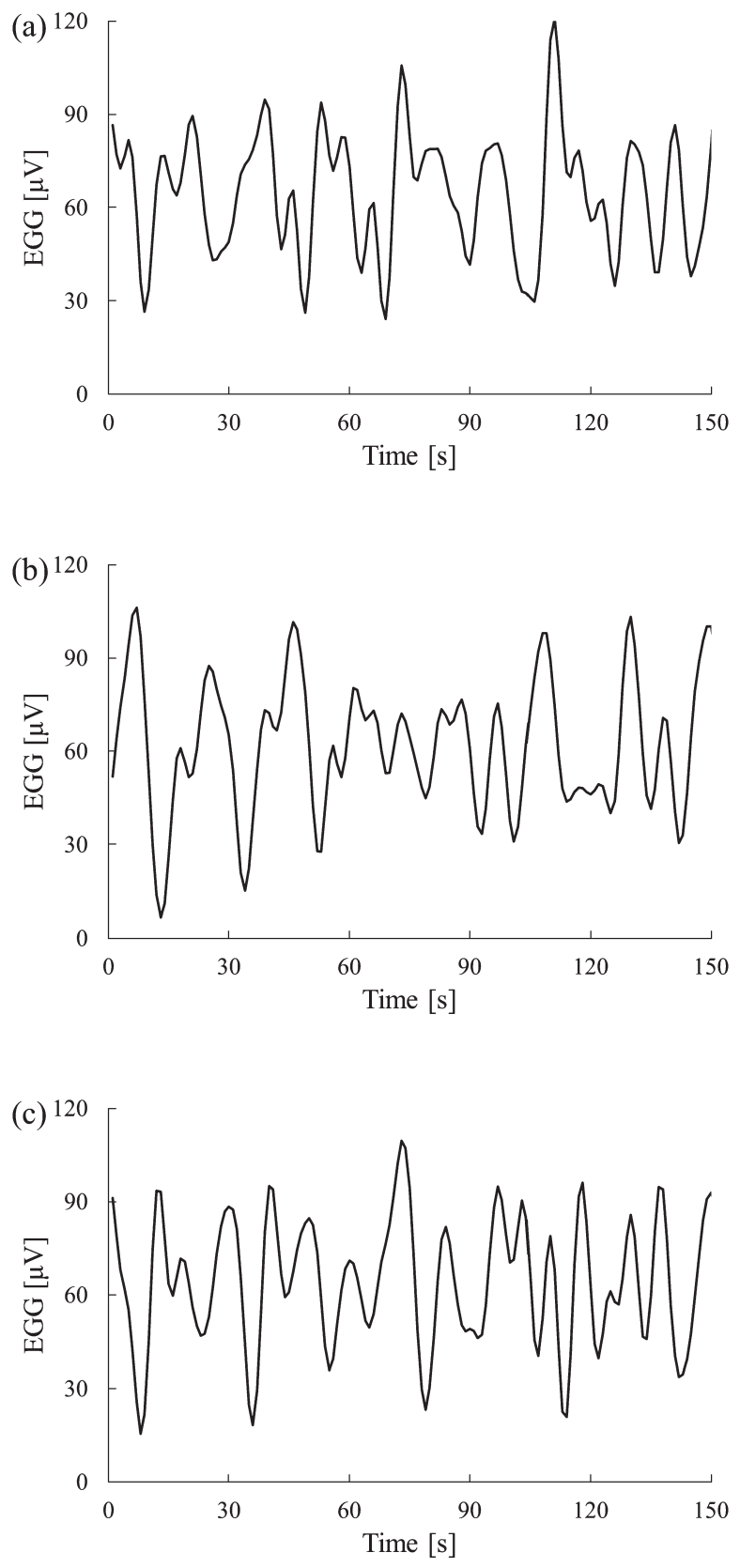

Fig. 3 Typical electrogastrogram. a, before viewing an video clip; b, viewing 2D video clip; c, viewing 3D video clip.

得られた動摇図から各解析指標を算出した。開眼検査 での結果 (平均土標準偏差) を Table 1 と示す。開眼検査 の各解析指標に扔いて視聴映像，視聴時間による差異を 因子とする二元配置分散分析を行った。その結果，視聴 映像を因子とした場合で外周面積, 総軌跡長に主効果が みられた $(\mathrm{p}<0.05)$ 。また，視聴時間による差異を因子と した場合で疎密度に主効果がみられた（ $\mathrm{p}<0.05 ）$ 。な抏, すべての指標で交互作用はみられなかった。開眼検査に 括いて $2 \mathrm{D}$ 映像視聴時では外周面積, 総軌跡長, 疎密度 で開始前に比べ值が減少し，立体映像視聴時では外周面 積, 総軌跡長で開始前に比べ值が増加した。Wilcoxonの 符号付き順位和検定の結果，2D 映像視聴開始後 60 分時 
Table 1 Analytical result of indices for stabilograms with open eye test (average \pm standard deviation)

\begin{tabular}{lcccc}
\hline viewing 2D video clip & $\begin{array}{c}\text { before viewing } \\
\text { open eye test }\end{array}$ & $\begin{array}{c}\text { viewing after 20 min } \\
\text { open eye test }\end{array}$ & $\begin{array}{c}\text { viewing after } 40 \text { min } \\
\text { open eye test }\end{array}$ & $\begin{array}{c}\text { viewing after } 60 \text { min } \\
\text { open eye test }\end{array}$ \\
\hline area of sway $\left[\mathrm{cm}^{2}\right]$ & $0.07 \pm 0.02$ & $0.05 \pm 0.01$ & $0.08 \pm 0.02$ & $0.04 \pm 0.01$ \\
total locus length [cm] & $48.1 \pm 1.7$ & $46.3 \pm 0.9$ & $47.5 \pm 1.4$ & $46.2 \pm 1.0$ \\
total locus length per unit area [1/cm] & $927.2 \pm 151.2$ & $1199.9 \pm 192.4$ & $804.4 \pm 146.0$ & $1363.5 \pm 113.0$ \\
sparse density & $1.37 \pm 0.08$ & $1.15 \pm 0.06$ & $1.21 \pm 0.06$ & $1.04 \pm 0.07$ \\
\hline viewing 3D video clip & before viewing & viewing after 20 min & viewing after 40 min & viewing after 60 min \\
& open eye test & open eye test & open eye test & open eye test \\
\hline area of sway $\left[\mathrm{cm}^{2}\right]$ & $0.06 \pm 0.01$ & $0.10 \pm 0.03$ & $0.20 \pm 0.12$ & $0.19 \pm 0.14$ \\
total locus length $[\mathrm{cm}]$ & $47.0 \pm 1.2$ & $49.1 \pm 1.7$ & $50.0 \pm 2.2$ & $50.0 \pm 1.7$ \\
total locus length per unit area $[1 / \mathrm{cm}]$ & $928.5 \pm 177.9$ & $979.1 \pm 290.8$ & $901.2 \pm 233.9$ & $951.3 \pm 218.9$ \\
sparse density & $1.41 \pm 0.04$ & $1.18 \pm 0.13$ & $1.19 \pm 0.11$ & $1.20 \pm 0.10$ \\
\hline
\end{tabular}

Table 2 Analytical result of indices for stabilograms with close eye test (average \pm standard deviation)

\begin{tabular}{|c|c|c|c|c|}
\hline viewing $2 \mathrm{D}$ video clip & $\begin{array}{l}\text { before viewing } \\
\text { close eye test }\end{array}$ & $\begin{array}{l}\text { viewing after } 20 \mathrm{~min} \\
\text { close eye test }\end{array}$ & $\begin{array}{l}\text { viewing after } 40 \mathrm{~min} \\
\text { close eye test }\end{array}$ & $\begin{array}{l}\text { viewing after } 60 \mathrm{~min} \\
\text { close eye test }\end{array}$ \\
\hline area of sway $\left[\mathrm{cm}^{2}\right]$ & $0.04 \pm 0.01$ & $0.06 \pm 0.02$ & $0.06 \pm 0.02$ & $0.07 \pm 0.01$ \\
\hline total locus length $[\mathrm{cm}]$ & $47.8 \pm 1.6$ & $48.1 \pm 0.7$ & $48.2 \pm 1.5$ & $48.4 \pm 1.1$ \\
\hline total locus length per unit area $[1 / \mathrm{cm}]$ & $1253.8 \pm 145.1$ & $1241.4 \pm 238.6$ & $1160.2 \pm 227.8$ & $1019.8 \pm 256.8$ \\
\hline sparse density & $1.11 \pm 0.12$ & $1.24 \pm 0.18$ & $1.17 \pm 0.11$ & $1.13 \pm 0.11$ \\
\hline viewing 3D video clip & $\begin{array}{l}\text { before viewing } \\
\text { close eye test }\end{array}$ & $\begin{array}{l}\text { viewing after } 20 \mathrm{~min} \\
\text { close eye test }\end{array}$ & $\begin{array}{l}\text { viewing after } 40 \mathrm{~min} \\
\text { close eye test }\end{array}$ & $\begin{array}{l}\text { viewing after } 60 \mathrm{~min} \\
\text { close eye test }\end{array}$ \\
\hline area of sway $\left[\mathrm{cm}^{2}\right]$ & $0.05 \pm 0.01$ & $0.14 \pm 0.07$ & $0.06 \pm 0.01$ & $0.07 \pm 0.01$ \\
\hline total locus length [cm] & $48.7 \pm 1.7$ & $50.1 \pm 2.0$ & $47.7 \pm 0.8$ & $49.4 \pm 1.5$ \\
\hline total locus length per unit area $[1 / \mathrm{cm}]$ & $1249.8 \pm 211.3$ & $943.2 \pm 365.5$ & $939.5 \pm 196.8$ & $945.5 \pm 178.4$ \\
\hline sparse density & $1.23 \pm 0.07$ & $1.17 \pm 0.11$ & $1.12 \pm 0.09$ & $1.26 \pm 0.07$ \\
\hline
\end{tabular}

Table 3 Analytical result of indices for electrogastrogram (average \pm standard deviation)

\begin{tabular}{lcccc}
\hline viewing 2D video clip & before viewing & viewing after 20 min & viewing after 40 min & viewing after 60 min \\
\hline peak frequency $[\mathrm{cpm}]$ & $3.52 \pm 0.30$ & $3.23 \pm 0.24$ & $3.66 \pm 0.42$ & $3.31 \pm 0.19$ \\
PSD $\left[\mu \mathrm{V}^{2}\right]$ & $0.18 \pm 0.02$ & $0.18 \pm 0.02$ & $0.17 \pm 0.01$ & $0.18 \pm 0.01$ \\
$E_{\text {trans }}$ & $0.39 \pm 0.01$ & $0.36 \pm 0.01$ & $0.38 \pm 0.01$ & $0.38 \pm 0.02$ \\
\hline viewing 3D video clip & before viewing & viewing after 20 min & viewing after 40 min & viewing after 60 min \\
\hline peak frequency [cpm] & $3.64 \pm 0.27$ & $3.20 \pm 0.15$ & $2.95 \pm 0.20$ & $2.96 \pm 0.21$ \\
PSD $\left[\mu \mathrm{V}^{2}\right]$ & $0.15 \pm 0.01$ & $0.19 \pm 0.01$ & $0.18 \pm 0.01$ & $0.17 \pm 0.01$ \\
$E_{\text {trans }}$ & $0.38 \pm 0.01$ & $0.38 \pm 0.01$ & $0.41 \pm 0.01$ & $0.41 \pm 0.01$ \\
\hline
\end{tabular}

の疎密度で開始前に比べ值が有意に減少した $(\mathrm{p}<0.05)$ 。 また，2D 映像視聴開始後 60 分時の総軌跡長抢よび立体 映像視聴開始後 40 分時, 60 分時の疎密度で開始前に比 べ值に減少傾向がみられた $(\mathrm{p}<0.10)$ 。2D 映像視聴開 始後 60 分時の単位面積軌跡長および立体映像視聴開始 後 20 分時，60 分時の総軌跡長で開始前に比べ值に増加 傾向がみられた $(\mathrm{p}<0.10)$ 。各解析指標に打いて $2 \mathrm{D}$ 映 像視聴時と立体映像視聴時での同時刻の值をそれぞれ比 較した。その結果, 映像視聴開始後 60 分時に打訂る外 周面積, 総軌跡長で $2 \mathrm{D}$ 映像視聴時に比べ立体映像視聴 時は值が有意に増加した $(\mathrm{p}<0.05)$ 。また，映像視聴開 始後 60 分時の単位面積軌跡長で $2 \mathrm{D}$ 映像視聴時に比べ 立体映像視聴時は值に減少傾向がみられた $(\mathrm{p}<0.10)$ 。

閉眼検査での結果 (平均土標準偏差)を Table 2 に示す。
閉眼検查の各解析指標に抢いて視聴映像，視聴時間によ る差異を因子とする二元配置分散分析を行った結果，す べての指標で主効果执よび交互作用はみられなかった。 Wilcoxonの符号付き順位和検定にて映像視聴開始前と 開始後の各解析指標を比較した結果，閉眼検査ではすべ ての指標で有意差はみられなかった。また，閉眼検査で の各解析指標に扮いて 2D 映像視聴時と立体映像視聴時 の同時刻をそれぞれ比較した結果，すべての時刻で有意 差はみられなかった。

分割した胃電図データに対し, 各解析指標を算出した。 結果 (平均土標準偏差) を Table 3 に示す。2D 映像視聴 開始後 20 分時のピーク周波数および並進誤差で開始前 比べ值が有意に減少した $(\mathrm{p}<0.05)$ 。また，立体映像視 聴開始後ではすべての時刻で開始前に比べピーク周波数 


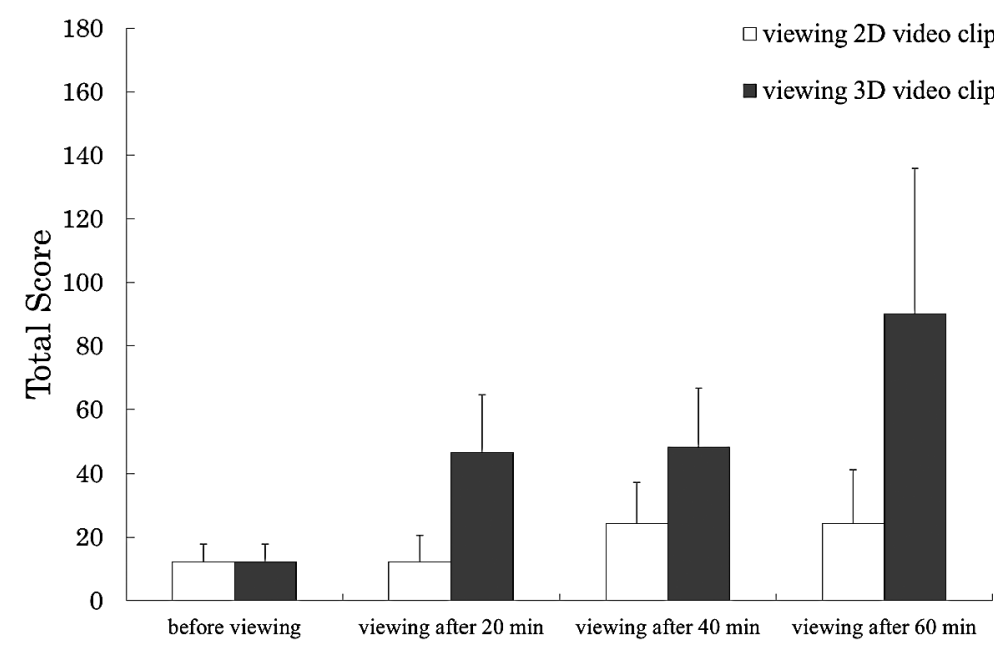

Fig. 4 SSQ total score (average)

の值が有意に減少した $(\mathrm{p}<0.05)$ 。立体映像視聴開始後 20 分時の PSD は開始前に比べ值が有意に増加し $(\mathrm{p}<$ $0.05)$, 立体映像視聴開始後 40 分時，60 分時の PSD は 開始前に比べ值に増加傾向がみられた $(\mathrm{p}<0.10)$ 。胃電 図データに括いて並進誤差の值はいずれも 0.4 近傍で変 動し, すべての時刻で 2D 映像視聴時に比べ立体映像視 聴時は值が大きくなった。

視聴時間の増加にともない, 眼疲労や映像酔いの程度 の変化を観察するために SSQを用いて主観的評価を 行った。SSQ，シミュレータ酔いに有効と考兄られ る 16 の主観評価項目を抽出したものである。映像視聴 開始前拈よび開始後でのトータルスコアの結果を Fig. 4 に示す。アンケートスコアの同値が多かったため有意差 はみられなかったものの, 視聴映像によらず時間経過に ともないトータルスコアの值は増加した。また, すべて の時刻に抢いて 2D 映像視聴時に比べ立体映像視聴時に トータルスコアの值は大きくなった。

\section{4. 考察}

本実験では重心動摇検査，胃電図検査，SSQにより 長時間の立体映像視聴が生体に及ぼす影響について検討 した。その結果, 重心動摇検査では映像視聴開始後 60 分時で視聴映像による差異が多くみられ, 胃電図検查沶 よびSSQ では映像視聴開始後 20 分時時から視聴映像に よる差異がみられた。

重心動摇の計測は，ロンベルグ姿勢やマン姿勢などの 立位による計測が一般的であり, 座位に着目した重心動 摇を用いた研究は数が少ない。しかし，自動車や電車， 船舶などの振れによって起こる乗り物酔い, シミュレー タや沉用 Virtual Environments（VE）を利用したことに よって生ずるVE酔いは，座位時に発生する例が多い。 しかし，座位による重心動摇の計測はほとんど行われて 抢らず，その計測手法も確立されていない。そのため, 乗り物酔いやVE 酔いといった座位での計測が望ましい 場合でも立位で計測が行われてきた。そこで，本論文で
は長時間の立体映像曝露が体平衡系に及ぼす影響につい て，座位による重心動摇検査の記録を試みた。重心動摇 検査を立位で行う場合，開眼検査に比べ閉眼検査では動 摇図の分散值は大きくなることが知られている(18)。 これは, 閉眼検査では起立時の手がかりとなる視覚情報 の消失に加え，120 秒間の連続直立による疲労が影響す るためである。しかし，本実験で行った座位による重心 動摇検査では開眼検査と閉眼検査の各解析指標を比較し た結果，すべての指標で有意差はみられなかった。これ は，座位による重心動摇検査では身体を支持するための 支持基底面が立位に比べ広く，重心位置も立位に比べ低 い位置にあることや，座位計測による疲労の減少が影響 したと考えられる。

一方, 開眼検查に括いて，2D 映像視聴時では開始前 に比べ各解析指標の值が安定になる傾向がみられたのに 対し, 立体映像視聴時では開始前に比べ各解析指標の值 が不安定になる傾向がみられた。特に，2D 映像視聴時 と立体映像視聴時では映像視聴開始後 60 分時で最も多 く各解析指標の值に有意差がみられ，SSQを用いた主 観的評価からも映像視聴開始後 60 分時で視聴映像によ る差異が最も大きくみられた。先行研究による長時間の 立体映像視聴の視機能と眼疲労に関する研究では, 2D 映像視聴時の主な視機能（屈折度, 瞳孔径, 眼位等）は 開始前と比較しても有意差がみられなかったのに対し， 立体映像視聴時では開始後 60 分時で調節近点の值で開 始前に比べ有意な延長および眼疲労を訴える割合の増加 が夕られている(19)。長時間の立体映像視聴は，瞳孔 筋や毛様体筋といった瞳孔括約筋の運動が長時間にわた り繰り返されることで, 筋疲労による視覚疲労が蓄積さ れ，前庭神経核を介した平衡機能に影響を及ぼしている 可能性が示唆される。

消化管運動活動における自律神経活動の指標として用 いた胃電図検査では，映像視聴開始後 20 分時では映像 の差異に関わらずピーク周波数が低下した。胃腸活動は 副交感神経活動の亢進によりその活動が活発になること から，映像視聴開始直後では副交感神経活動が抑制され 
る可能性がある。また，2D 映像視聴時ではピーク周波 数の低下は開始後 20 分時でのみみられたのに対し，立 体映像視聴時ではすべての時刻でピーク周波数の低下が みられた。さらに, 正常周期での PSD は，2D 映像視聴 時では視聴前後で変化がみられなかったのに対し，立体 映像視聴時では開始前に比べすべての時刻で值に増加傾 向がみられた。また, 胃電図から推定される並進䛊差は, $2 \mathrm{D}$ 映像視聴時に比べ立体映像視聴時では胃の電気活動 が不規則になる傾向がみられた。

胃電図検査の結果から，映像視聴開始直後では映像の 差異に関わらず，副交感神経活動は抑制され，映像の視 聴時間が長くなることで映像の差異による副交感神経活 動の抑制継続時間に影響がみられた。また，映像視聴が 胃腸の自律神経活動に及ぼす影響の応答速度は体平衡系 のそれに比べ速く応答することが確認された。自律神経 活動が体平衡系に拈ける運動出力に関与することから も，立体映像を長時間視聴することで自律神経系に及ぼ す影響が大きくなり，映像の差異による重心動摇検査の 結果に影響を及ぼした可能性が示唆された。

\section{5. ま と め}

本論文では重心動摇検査，胃電図検査，SSQを用い て多角的に長時間の立体映像視聴が生体に及ぼす影響に ついて検討し，長時間の立体映像視聴により不快感が生 じていることを主観的，客観的に評価した。重心動摇検 査は，身体を支持するための支持基底面が小さい不安定 な直立姿勢で行うことが一般的である。これは，直立姿 勢が外乱による立位制御系の変化や体平衡系の異常を反 映しやすいためである。しかし，重心動摇検査の測定姿 勢として座位を用いることは，立位姿勢の困難な患者や 高歯者などで新たな知見を得ることが可能とする。そこ で，本論文では長時間の立体映像曝露が体平衡系に及ぼ す影響について，座位を用いた重心動摇検査で検討を 行った。その結果, 立体映像を長時間視聴することで動 摇図は不安定になる傾向を示した。また，重心動摇検査 を座位で行う場合，座位では身体を支持するための基底 面が立位に比べ広く，重心位置も立位に比べ低い位置に あることから立位に比べ動摇図分布の広がりは小さくな る。そこで，既存の解析手法である外周面積や総軌跡長 に加え, 動摇図を構成する時系列の微小な变動に対し, 非線形性を考慮する解析手法が必要であると考兄られ る。また，立体映像視聴が生体に及ぼす影響について胃 電図検査を同時計測することで，体平衡系の応答速度が 消化管運動の応答速度に比べ遅延があることが確認され た。立体映像が生体に及ぼす影響についての知見は未だ 十分でなく，そのメカニズムも解明されていない。立体 映像の安全な視聴には, 実証研究の蓄積に加光, その影 響を定量的に評価していくことが必要である。

本論文は利益相反なしである。

\section{文献}

( 1 ) Suyama S, Date M, Takada H. Three dimensional display system with dual frequency liquid crystal varifocal lens. Jpn J Appl Phys 2000;39:480-484.

( 2 ) Gabor D. A new microscopic principle. Nature 1948;161: 777-779.

( 3 ) International Standard Organization. IWA3 2005 Image Safety-Reducing Determinism in a Time Series. Phys Rev Lett 1993;70:530-582.

（4）矢野澄男，井出真司. 立体映像の見やすさと調節変動 からみた視覚疲労. 映像メディア学会誌 2001;55(5): 711-717.

( 5 ) Reason JT, Brand JJ. Motion Sickness. London: Academic Press, 1975.

( 6 ) Barmack NH. Central Vestibular System: vestibular nuclei and posterior cerebellum. Brain Res Bull 2003;60:511-541.

( 7 ) Okawa T, Tokita T, Shibata Y, Ogawa T, Miyata H. Stabilometry: Significance of locus length per unit area (L/A). Equilibrium Research 1995;54(3):296-306.

（８）鈴木淳一, 松本 喬, 徳増厚二, 田口喜一郎, 渡辺行 雄．重心動摇検査の Q\&A 手引き（1995）．Eqquilibrium Research 1996;55(1):64-77.

( 9 ) Takada H, Amemori M, Matsuura Y. Stabilometry in Sitting Position. IEEJ Trans PE, Information and Systems Society 2012;132(10):1558-1562.

(10) Alvarez WC. The electrogastrogram and what is shows. J Am Med Assoc 1922;78:1116-1119.

(11) Cajal SR. Historogie du systeme nerveux de l'homme et des vertebras. 1911;2:942. (in French) (reprinted in English, Cajal SR, Swanson N, Swanson LW. Histology of the Nervous System of Man and Vertebrates. UK: Oxford University Press, 1995)

(12) Homma S. Isopower mapping of the erectrogastogram (EGG). J Auton Nerv Syst 1997;62:163-166.

(13) Nelsen TS, Becker JC. The electrogastrogram and what is shows. J Am Med Assoc 1922;78:1116-1119.

(14) Takada H, Kitaoaka Y, Ishikawa M, Miyao M. Physical meaning on geometrical index for stabilometry. Equilbrium Research 2003;62(3):169-180.

(15) Nozaki D, Collins JJ, Yamamoto Y. Mechanism of stochastic resonance enhancement in neuronal models driven by 1/f noise. Phys Rev E 1999;60:4637-4645.

(16) Wayland R, Bromley D, Pickett D, Passamante A. Recognizing determinism in a time series. Phys Rev Lett 1993;70: 530-582.

(17) Kenneth LK, Robert M. Handbook of Electro Gastrography. Oxford University Press, 2004

(18) Imaoka K, Murase H, Fukuhara M. Collection of data for healthy subjects in stabilometry. Equilibrium Research 1997;12:1-84.

(19) Namba T, Kobayashi Y, Tabuchi A, et al. Examination of visual function and asthenopia after continuous watching of three-dimensional images. Folia Japonica de Ophthalmologica Clinica 2013;6(1):10-16. 